\title{
Two centuries of spreading language loss
}

\author{
Gary F. Simons*
}

\begin{abstract}
This paper presents a visual depiction of the global spread of language loss over the past two centuries. This is done via a series of world maps (from 1795 to the present by 25-year intervals) in which each country is colored to represent the percentage of its indigenous languages that had died by that year or were doomed to die since they were no longer being used by children. A major finding is that the current rate of language loss is 9 per year, or one every 40 days - a far cry from the widely cited, "One language dies every 14 days." Nevertheless, the rate of language loss is increasing and is on a trajectory to reach that level by the middle of the next century. An investigation of trends by world regions shows that the rate of language loss has already peaked in the Americas and Australia, remains relatively low in subSaharan Africa, and is accelerating sharply in the rest of the world.
\end{abstract}

Keywords. endangered languages; language shift; language death; global trends

1. Introduction. Languages have a crucial function in the everyday lives of everyone. But indigenous peoples around the world are facing a crisis of language loss on an unprecedented scale. The UN General Assembly on 22 November 2016 adopted a resolution on "Rights of indigenous peoples." Among other things, it proclaims 2019 to be the International Year of Indigenous Languages (IYIL) in an effort to bring attention to "the critical loss of indigenous languages and the urgent need to preserve, revitalize and promote indigenous languages at the national and international levels" (UNESCO 2016).

The declaration of 2019 as the IYIL motivated the editorial staff of Ethnologue to work toward contributing an authoritative picture of the global trends with respect to language loss. Therefore, we put a focus on data concerning language shift and language death in working toward the $22^{\text {nd }}$ edition (Eberhard et al. 2019), released on International Mother Language Day (February 21). This paper presents the global picture of language loss that emerges from those data.

2. Problem. Michael Krauss (1992) got the attention of the linguistics community when he warned of the impending doom of the vast majority of human languages. After describing outcomes already realized in Australia and North America, and noting global trends like urbanization and deforestation, he observed that "I consider it a plausible calculation that - at the rate things are going - the coming century will see either the death or the doom of $90 \%$ of mankind's languages" (Krauss 1992: 7). While the prospect of $90 \%$ loss may seem extreme, a consensus seems to have developed around the likelihood of 50\% loss. For instance, Crystal (2000: 19) suggests that "a middle position of $50 \%$ loss ... cannot be very far from the truth," and then observes that this would require that "at least one language must die, on average, every

\footnotetext{
* The impetus for producing the visualization of spreading language loss through a map series came from Wilhelm Meya, CEO of The Language Conservancy; I owe much to his vision and encouragement. For their help in pulling together the dataset, I am deeply indebted to my fellow Ethnologue editors, Dave Eberhard and Chuck Fennig, and especially to research assistant Kiersten Henkel who spent more time than anyone tracking down information on when last speakers died. Finally, I want to acknowledge the hundreds of SIL colleagues and friends whose contributions over the decades have made the Ethnologue into the amazing resource that it is. Author: Gary F. Simons, SIL International (gary_simons@sil.org)
} 
two weeks or so." It was not long before this conjecture got picked up by the media and reported as a fact (e.g., Rymer 2012: 60). At the time of writing an exact Google search for "one language dies every 14 days" yields over 3,000 hits; an exact search for "one language disappears every two weeks" reports over 500 hits.

In reality, the currently observed rate of language loss is well less than this. One objective of this paper is to addresses the problem of rampant misinformation about the current rate of language loss; the results in section 4 report on the facts of the present-day situation, using maps and trend lines to situate the present in terms of what has been taking place over the past two centuries. A second objective of the paper is to shed some light on the outlook with respect to language loss in the future; the results also plot trend lines that allow us to anticipate the trajectory of language loss into the next century. The methodology involves using the generational logic built into EGIDS, the Expanded Graded Intergenerational Disruption Scale, to project rates of language loss in the near future. Section 3 begins by describing the method that was used to construct the dataset behind the maps and graphs in section 4 .

\section{Methodology}

3.1. A TOOL FOR ASSESSING LANGUAGE VITALITY. Joshua Fishman, in his seminal book Reversing Language Shift (1991), developed the Graded Intergenerational Disruption Scale (GIDS) as a measuring rod for the level of threat to the long-term maintenance of a given language. He conceptualized threat in terms of disruption to the prospects that a language will continue to be handed down intergenerationally (1991: 87). The scale consists of eight levels, numbered 1 to 8, representing increasing levels of threat or disruption. Since the scale measures disruption, the lowest number represents the least threat to the disruption of intergenerational transmission, while the highest number represents the most. At level 1, representing virtually no threat to survival, is an official national language that is used in written form for the business of government and in which literacy in the language is passed down through a national system of compulsory education. At level 8, representing virtually assured language death, is a language spoken only by the elderly. The six levels in between represent successively fewer functions for language in society as the level of disruption increases.

The basic premise of GIDS is that language shift (ending in language death) happens as a language loses functions in society. To reverse language shift, the community must work to bring those functions back. To guard against future shift, the community can work to add new functions that further strengthen the position of the language. As a language adds functions it is said to develop (Simons 2011). The bulk of Fishman's book consists of case studies describing situations in which this has happened. The magnitude of the numbers in the scale notwithstanding, it has been conventional to view the strongest languages as being at the top of the scale and the weakest languages as being at the bottom (e.g., Fishman 2001: 466). Thus the basic premise of GIDS can be visually summarized as shown in Figure 1.
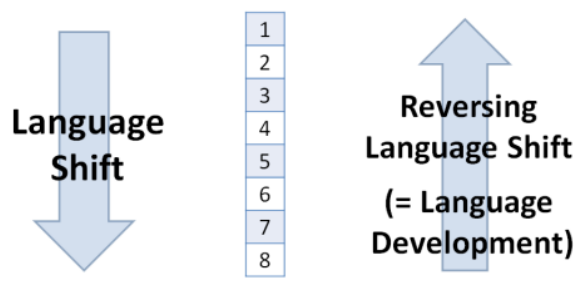

Figure 1. The basic premise of GIDS 
3.2. USING EGIDS TO ASSESS LANGUAGE VITALITY ON A GLOBAL SCALE. Ethnologue gives a basic description of the location and situation of every known language of the world. In planning for the development of the seventeenth edition (Lewis et al. 2014), we determined that we wanted to add a new feature - an estimate of linguistic vitality for each language. We felt that the GIDS would be an excellent tool for this purpose since it covers the whole range from strongest to weakest. However, in implementing this for Ethnologue, we encountered the following issues:

- In order to have a level for every language, we needed to add extinct languages at the bottom of the scale. In doing this we wanted to keep the Ethnologue distinction between dormant languages (which have no fluent speakers but still have an identificational function within an ethnic community) and truly extinct languages (which have no function within any living ethnic community).

- We noted that even official national languages are being impinged upon by the languages of globalization. We thus added a new level for international languages at the top of the scale.

- Language endangerment is a major issue, but GIDS distinguishes only two levels of endangerment: level 7 in which there is active use of the language but only among adults and level 8 in which the only remaining speakers are "socially isolated old folks" (Fishman 1991: 88). In order to produce a scale that harmonizes with the four levels of endangerment recognized in the UNESCO Atlas of the World's Languages in Danger (Moseley 2010) we split two of the levels of the original GIDS.

The result is a scale that has 13 levels which we dubbed EGIDS, for Expanded GIDS (Lewis and Simons 2010). Following the initial publication, minor refinements followed as EGIDS was applied to every language described in Ethnologue. The fullest description of EGIDS is now found in Lewis and Simons 2016, which also discusses how insights of the model can be used in planning language development efforts that seek to sustain language use in the face of pressures to shift. Table 1 reproduces the entire scale as defined in Lewis and Simons 2016. The final column of the table gives the nearest equivalent from the UNESCO language endangerment scale.

3.3. THE GENERATIONAL LOGIC OF EGIDS. From the point of view of language vitality, the single most significant break in the EGIDS scale is the divide between 6a and 6b. For languages that are 6a and higher, it is the norm that the language is being passed on to all the children within its user community. But at level $6 \mathrm{~b}$ and below, this is no longer the norm and intergenerational transmission is being disrupted. At level 6a there may be other languages in the environment and there may even be a few children who learn them instead of their heritage language; but those cases are anomalies. The status changes to level $6 \mathrm{~b}$ when there are enough children learning a different language that members of the community begin noticing that there is a growing trend. At the outset of level 6b, the majority of children are still learning the traditional language, and the language will continue to be sustained if they in turn pass the language to their children. But if the trend toward learning a different language keeps increasing, the day will eventually come when there are no longer any young people who speak the language. At that point, the language enters level 7 and progression through the remaining levels of the scale follows progression through the generations of the human life span. The diagnostic question for assigning an EGIDS level within a language community that has begun to experience language shift is, "What is the generation of the youngest L1 users of the language?" This is illustrated in Table 2. 


\begin{tabular}{|c|c|c|c|}
\hline Level & Label & Description & UNESCO \\
\hline 0 & International & $\begin{array}{l}\text { The language is widely used between nations in trade, } \\
\text { knowledge exchange, and international policy. }\end{array}$ & Safe \\
\hline 1 & National & $\begin{array}{l}\text { The language is used in education, work, mass media, and } \\
\text { government at the national level. }\end{array}$ & Safe \\
\hline 2 & Provincial & $\begin{array}{l}\text { The language is used in education, work, mass media, and } \\
\text { government within major administrative subdivisions of a } \\
\text { nation. }\end{array}$ & Safe \\
\hline 3 & $\begin{array}{l}\text { Wider Com- } \\
\text { munication }\end{array}$ & $\begin{array}{l}\text { The language is used in work and mass media without offi- } \\
\text { cial status to transcend language differences across a region. }\end{array}$ & Safe \\
\hline 4 & Educational & $\begin{array}{l}\text { The language is in vigorous use, with standardization and } \\
\text { literature being sustained through a widespread system of } \\
\text { institutionally supported education. }\end{array}$ & Safe \\
\hline 5 & Developing & $\begin{array}{l}\text { The language is in vigorous use, with literature in a standard- } \\
\text { ized form being used by some though this is not yet } \\
\text { widespread or sustainable. }\end{array}$ & Safe \\
\hline $6 a$ & Vigorous & $\begin{array}{l}\text { The language is used for face-to-face communication by all } \\
\text { generations and the situation is sustainable. }\end{array}$ & Safe \\
\hline $6 b$ & Threatened & $\begin{array}{l}\text { The language is used for face-to-face communication within } \\
\text { all generations, but it is losing users. }\end{array}$ & Vulnerable \\
\hline 7 & Shifting & $\begin{array}{l}\text { The child-bearing generation can use the language among } \\
\text { themselves, but it is not being transmitted to children. }\end{array}$ & $\begin{array}{l}\text { Definitely } \\
\text { endangered }\end{array}$ \\
\hline $8 a$ & Moribund & $\begin{array}{l}\text { The only remaining active users of the language are mem- } \\
\text { bers of the grandparent generation and older. }\end{array}$ & $\begin{array}{l}\text { Severely } \\
\text { endangered }\end{array}$ \\
\hline $8 b$ & Nearly Extinct & $\begin{array}{l}\text { The only remaining users of the language are members of the } \\
\text { grandparent generation or older who have little opportunity } \\
\text { to use the language. }\end{array}$ & $\begin{array}{l}\text { Critically } \\
\text { endangered }\end{array}$ \\
\hline 9 & Dormant & $\begin{array}{l}\text { The language serves as a reminder of heritage identity for an } \\
\text { ethnic community, but no one has more than symbolic profi- } \\
\text { ciency. }\end{array}$ & Extinct \\
\hline 10 & Extinct & $\begin{array}{l}\text { The language is no longer used and no one retains a sense of } \\
\text { ethnic identity associated with the language. }\end{array}$ & Extinct \\
\hline
\end{tabular}

Table 1. The 13 levels of EGIDS

\begin{tabular}{cl} 
EGIDS level & Generation of youngest L1 users \\
\hline $6 \mathrm{~b}$ & Children or youth \\
7 & Parents \\
$8 \mathrm{a}$ & Grandparents \\
$8 \mathrm{~b}$ & Great-grandparents \\
9 & No L1 users remain \\
\hline
\end{tabular}

Table 2. Assigning EGIDS levels for language communities in language shift

Returning to Krauss's (1992: 7) warning that "the coming century will see either the death or the doom of $90 \%$ of mankind's languages," how do the levels of EGIDS relate? He explains what he means by being doomed as follows: "Languages no longer being learned as mother-tongue by 
children arc beyond mere endangerment, for, unless the course is somehow dramatically reversed, they are already doomed to extinction" (Krauss 1992: 4). Thus a language is "doomed" in Krauss's terms when the youngest speakers are young adults; this is EGIDS 7. A generation later, they are middle-aged (EGIDS 8a); a generation later, they are elderly (EGIDS 8b); and in one more generation, the last speaker will have died (EGIDS 9). The year when the last L1 speaker died is taken as the year of language death. Knowing that year, we can go back three generations to estimate when the language became doomed (i.e., reached EGIDS 7). This is the logic that underlies the construction of the dataset for this study.

3.4. OPERATIONALIZING THE DURATION OF A GENERATION. In order to construct a dataset about the year when languages became doomed, we must operationalize the notion of going back three generations from the death of the last L1 speaker into the operation of subtracting a specific number of years. This depends on estimating the age of the last speaker. This might seem problematic since average life expectancies vary widely across the world. The World Bank (2019) publishes data showing an average of 39.5 in 1960 for low income countries up to an average of 80.4 in 2016 for high income countries. However, the last speaker is the longest surviving member of a group, so average life expectancy is not in play. Other data (United Nations 2017) show that even where average life expectancy is low, there is still a significant number of people who survive into their nineties and we thus take "90-something" as the typical age of the last speaker. Subtracting 75 years from the year of death yields the year when the last speaker entered the late teens or early twenties. We use the result of that calculation as the estimate of the year of doom.

Taking 75 years as the duration of three generations gives us a duration of 25 years for each generation. Thus the sequence of maps generated in this study works back from the present by 25 -year intervals to depict the spread of language loss over the past two centuries. The actual year mapped is rounded to the nearest 0 or 5 ; thus the sequence is $1795,1820,1845,1870$, etc. Each map depicts the state of language doom by the end of that year, with the final map for 2018 representing the state of things at present.

3.5. CONSTRUCTING A GLOBAL DATASET ON LANGUAGE DEATH AND DOOM. Against the backdrop of language loss, there is an ever-present counterforce of language genesis. This study seeks to document only the trajectory of language loss over the past few centuries, leaving the investigation of trends in language genesis for a separate study. The objective was thus to create a dataset containing every language known to have been used as a first language (L1) in 1700 and track the spread of language loss for those languages.

Construction of the dataset began with the 2018 edition of the Ethnologue Global Dataset (Simons and Fennig 2018). It contains information like location, population, classification, and EGIDS level for the 7,467 languages reported in that edition. The first step was to remove languages that were not in scope for this study. This includes 12 ancient literary languages that were extinct long before 1700 but are listed as dormant because they remain in use today as the language of liturgy or scriptures for faith communities. Also out of scope are languages that did not yet have L1 users in 1700. The Ethnologue database has yet to identify the time frame in which languages of recent origin actually developed, but two classes of languages have been excluded from this study as typically being of recent origin. The first of these is sign languages (of which Ethnologue lists 141); for instance, American Sign Language developed in schools for the deaf in the early $19^{\text {th }}$ century (Fox 2007: 34-35). The second category is pidgins and creoles (of which Ethnologue lists 101). For instance, the English-based pidgins of Melanesia did not develop until the $19^{\text {th }}$ century. Even Atlantic creoles, which may have been in use as pidgins by 1700 , did not typically have communities of L1 speakers by that time. 
Absent from the 2018 dataset was information for the dormant and extinct languages on the year the last speaker died. Filling this gap required research by the editorial staff to add a statement on approximate time of language death; these statements appear as new additions to the 2019 edition of Ethnologue. Occasionally the year of death of a specifically identified last speaker was found, but typically the best that could be done was to approximate the year of death in terms of a decade. Such statements were variously worded depending on the information in the sources; for instance, "Last speaker died by 1980," "Last speaker died in the 1980s," or "Last speakers survived into the 1980s." For the sake of the statistical dataset, these statements were converted to estimated years as 1980, 1985, and 1990, respectively. In some cases, the best we could do was to estimate by portion of century, as in "Probably extinct by mid $20^{\text {th }}$ century" or "Survived into the late $19^{\text {th }}$ century" (with conversion to estimated years as 1950 and 1885).

The editorial policy of Ethnologue has been to describe every language listed in the ISO 639-3 standard (http://iso639-3.sil.org) that was living at the time Ethnologue began publishing in 1951, with dormant (or sleeping) languages being counted as living. Languages that were extinct by 1950 were not in the database. Therefore, in order to push the time horizon for this study back two centuries, it was necessary to add languages that became extinct at an earlier time. To complete the dataset, the editorial staff also determined the approximate year of death for every language identified as extinct in ISO 639-3 that was not in the Ethnologue database. Every language that became extinct after 1700 was added to the dataset for this study.

The resulting dataset contains 7,268 languages that were known to have had L1 speakers in 1700. Of these, 701 are reported to now be dormant or extinct. We were able to determine an approximate year of death of the last speaker for all but 18 of these languages. Given that this is such a small number relative to the total and that the missing years of death are likely distributed across the whole time frame of the study, these missing data are not thought to significantly impact the results. For the time series maps (section 4.2), these languages are treated as though they became extinct within the last 25 years. In this way, they begin to show up as a doomed language within their country by 1945 . For the analysis of the changing rate of language doom (sections 4.3 and 4.4), a correction is made to the number of languages doomed per generation up to 1945 such that these 18 languages are distributed across the generations in proportion to the number of languages that are known to have become doomed in each generation.

Given the EGIDS level of all 7,268 languages and the approximate year of last-speaker death for the languages that are dormant or extinct, the final step in constructing the dataset was to add a data column for the year of doom, that is, the approximate time at which the language was no longer being used by children. For languages that are not doomed (EGIDS level of $6 \mathrm{~b}$ or higher) there is no such value. For languages that are already dormant or extinct, the year of doom is simply calculated as the estimated year of last-speaker death minus 75 . Since the objective is to create a time-series map by 25-year generations, the resulting year of doom is then rounded up to the next highest year in the mapping sequence to indicate the first map on which it will be counted as being doomed. For languages that have remaining L1 speakers but are currently doomed, the year of doom is determined by the EGIDS level. For EGIDS 7, the present day map is the first one on which the language is doomed, since 25 years ago the current youngest speakers would have been children or youth. For EGIDS 8a, the year of doom is set to 1995. For EGIDS 8b, the year of doom is set to 1970. For EGIDS 9 and 10, it is 1945 or earlier, depending on the estimated year of the last speaker's death.

3.6. GENERATING THE RESUlTS. The manipulation and visualization of the data were done using $\mathrm{R}$ - open source software for statistical computing and graphics (https://www.r-project.org/). 
Data transformations were performed with the dplyr package (Wickham and Grolemund 2017). The graphs were created using the ggplot 2 package (Wickham 2010) and the map series was created using the tmap package (Lovelace et al. 2019).

\section{Results}

4.1. OVERVIEW OF PRESENT-DAY LANGUAGE VITALITY. Figure 2 summarizes the present-day state of language vitality worldwide by showing the distribution of EGIDS levels for the 7,268 languages in the dataset. 4,035 (or 55.5\%) of the languages in use in 1700 remain in vigorous use today; these are the EGIDS levels colored in green in the bar chart. 1,483 (or 20.4\%) of the languages are losing speakers to language shift, but are still being used within the youngest generation so we cannot predict when they might become extinct; these languages are represented by the yellow bar. 1,049 (or 14.4\%) of the languages still have living L1 speakers, but are likely doomed since they are no longer used by youth; these EGIDS levels are colored in red. Finally, 701 (or 9.6\%) of the languages living in 1700 are now dormant or extinct; these are depicted in black.

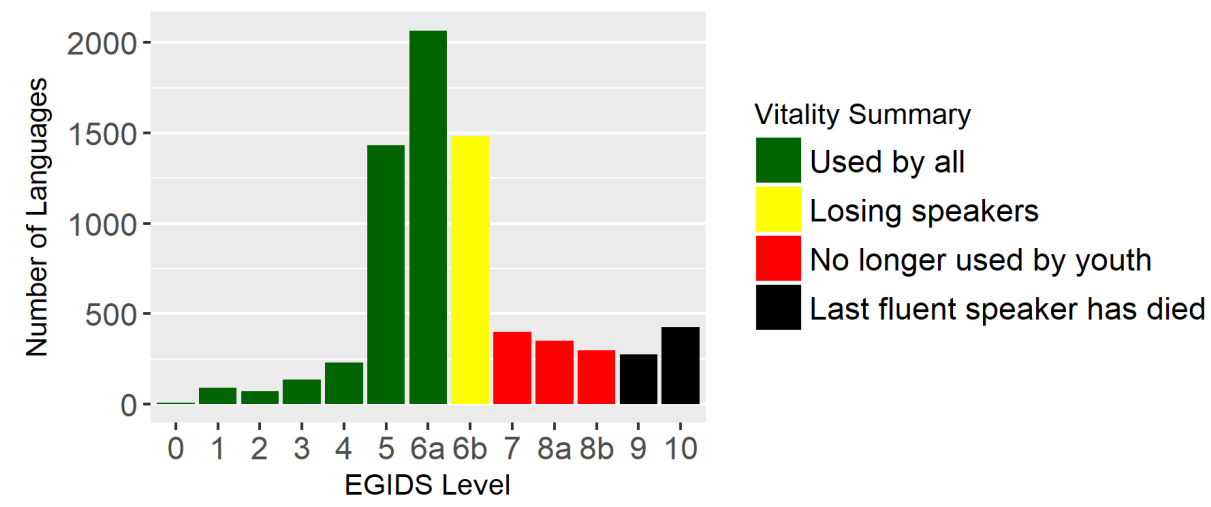

Figure 2. Present-day vitality of languages that were living in $1700(n=7,268)$

4.2. A VISUALIZATION OF SPREADING LANGUAGE LOSS. The main impetus behind this research was a desire to develop a visualization of the global spread of language loss over the past two centuries. The result is given in Figure 3, which shows a series of world maps (from 1795 to the present by 25-year intervals) in which each country is colored to represent the percentage of its indigenous languages that were extinct or doomed by that year. If the homeland of a particular language crosses a border, then it is counted as an indigenous language in both countries. The color scale goes from deep green for countries with virtually no language loss to a deep red for countries in which at least $80 \%$ of the indigenous languages have either become extinct or are no longer used by children. A key for the level of language loss depicted by the other colors in the scale is found in the lower left corner of each map. A gray color indicates that the dataset has no indigenous languages for that country; presumably they were lost without a record.

The sequence of maps in Figure 3 is like the frames of a movie that documents the spread of language doom since 1795. Advancing frame-by-frame provides an "animation" of the global spread of language loss as the colors change from deep green to light green to yellow to orange to red. In the initial frame, deep green dominates with fewer than ten countries having begun to change color. By the final frame, deep green is in the minority and the shades depicting significant language loss have begun to dominate. 

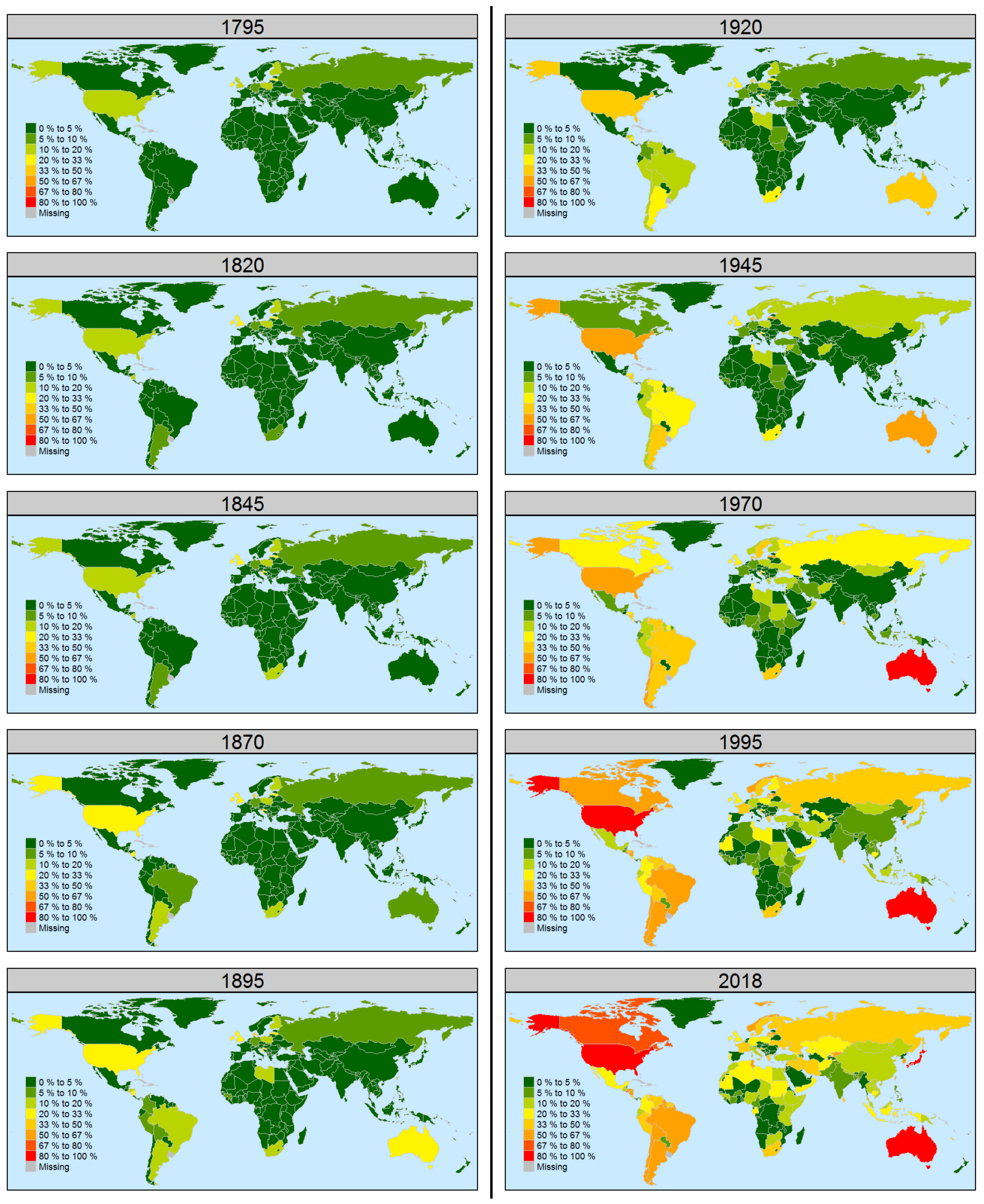

Figure 3. Percentage of doomed or extinct indigenous languages by 25 -year generations

Note that the maps in Figure 3 also depict the percentage of dormant or extinct languages three generations later. Thus one could add 75 years to the label above each map and change the figure caption to read "Percentage of dormant or extinct indigenous languages." For instance, the 1945 
frame also depicts the percentage of indigenous languages that have fallen silent as of today. The final frame in the sequence anticipates what the picture will look like in 2095 after the last speakers of today's EGIDS 7 languages have died.

4.3. ANNUAL RATE OF LANGUAGE LOSS. Figure 3 clearly gives the impression of an accelerating rate of language loss over the past ten generations. Figure 4 plots this explicitly. For each 25 -year period in the study, it plots the average number of languages for which the last speaker died (that is, the total number of language deaths in the period divided by 25). That average number is then plotted at the middle year within the period (for instance, the period ending 1795 is plotted at the midpoint between 1771 and 1795).

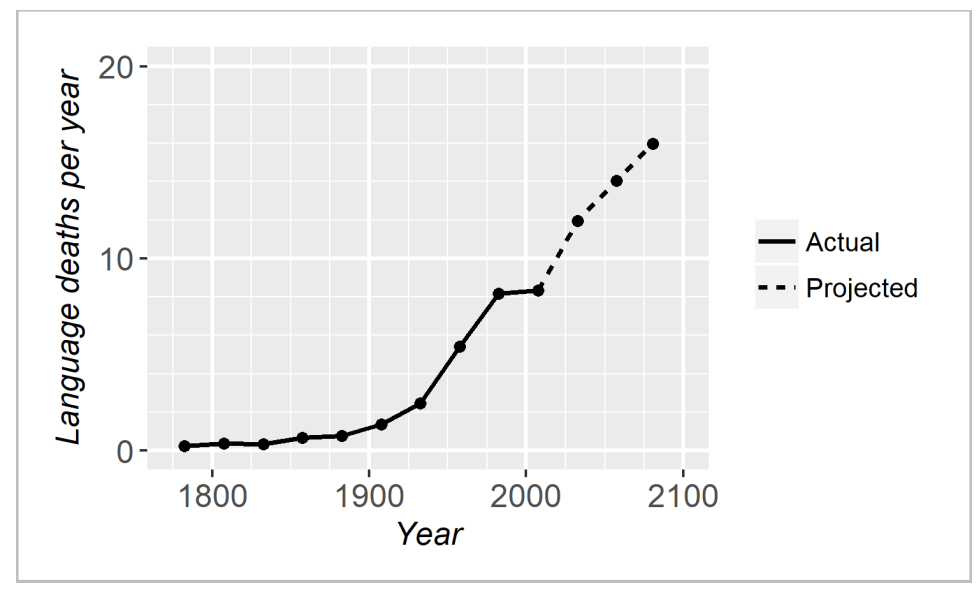

Figure 4. Language deaths per year

The solid trend line plots the actually observed rate of language death over the past two centuries. At present the rate is about 9 languages per year, or one language dying every 40 days. The dashed line plots the anticipated rate of language death as the languages currently at EGIDS levels $8 \mathrm{~b}, 8 \mathrm{a}$, and 7 reach the point at which the last speakers will have died. This indicates a rate of 16 language deaths per year by 2080. The much-publicized outcome of "one language dies every 14 days" would amount to a rate of 26 language deaths per year. It does not appear that this will be true even by the end of this century, but if the trend line shown in Figure 4 is extrapolated into the future, it reaches 26 languages per year by the middle of the next century.

4.4. TRENDS BY WORLD REGIONS. The early frames of the map series in Figure 3 corroborate the observation by Mufwene (2002) that settlement colonization led to language loss whereas exploitation colonization did not. The first countries to reach $20 \%$ language doom by the early $20^{\text {th }}$ century were places where settlement was the strategy: the United States, Australia, South Africa, and Argentina. Another study based on Ethnologue data goes more deeply into language endangerment in relation to settlement colonization versus exploitation colonization (Simons and Lewis 2013).

Whereas the Americas and Australia stand out in the map series as having led the global trend toward language loss, sub-Saharan Africa stands out as the only major region where the rate of loss is still under $10 \%$ on average. In the rest of the world, the amount of language loss is significantly higher than sub-Saharan Africa, but significantly lower than the Americas and Australia.

Figure 5 plots the trends for these three parts of the world. The points in the graph represent the number of languages that became doomed in the given region during each of the 25-year 
periods. The points are plotted at the last year of the period. The line for the Americas and Australia shows that the rate of language doom was rising sharply in the second half of the $19^{\text {th }}$ century, but leveled off in the $20^{\text {th }}$ century and is now falling. The line for sub-Saharan Africa shows that an epidemic of language loss has yet to take hold in that region. But the line for the remainder of the world shows that the doom of languages has risen at an alarming rate since 1945. The slope of the increase over the past three generations is even steeper than it was during the three generations in the Americas and Australia (1845-1920) when the rate of language loss rose the most sharply.

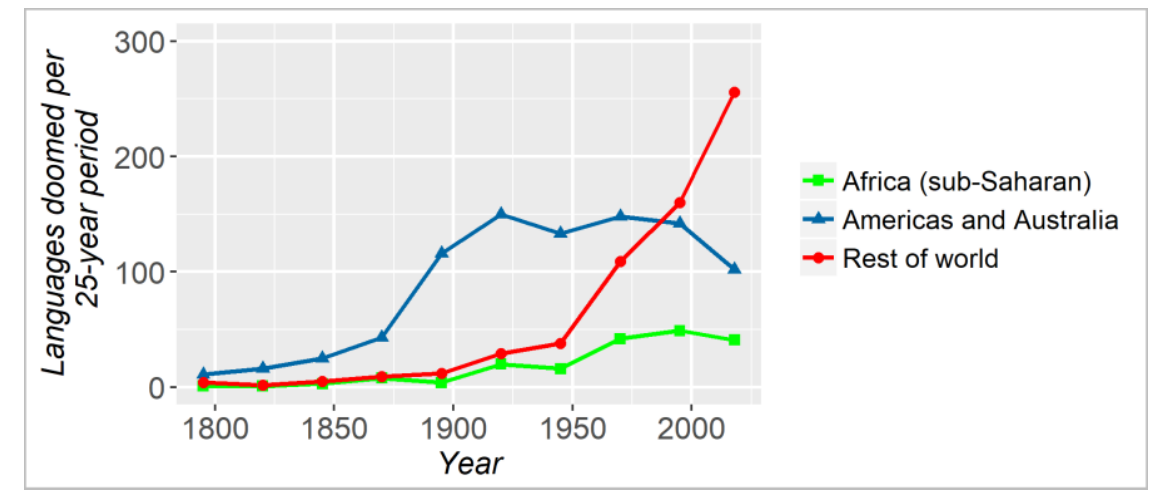

Figure 5. Language doom trends by world region

Whereas the settlement pattern of colonization seems to explain the sharp rise in language loss that began in the middle of the $19^{\text {th }}$ century in the Americas and Australia, the sharp rise elsewhere in the middle of the $20^{\text {th }}$ century is likely explained by other forces like rising nationalism, globalization, and urbanization. The latter is particularly worrisome for the future of minoritized indigenous languages, since just like settlement colonization, it is moving people away from their ancestral land (Simons and Lewis 2013: 16-17). However, in contrast to the blatant injustice of displacement through forced resettlement, urbanization is a more insidious force in that indigenous peoples are voluntarily leaving their rural homelands and migrating to urban centers where they use dominant languages in order to participate in the urban economy. Of the major world areas, sub-Saharan Africa and Asia are the least urbanized; consequently, they are where the fastest urban growth is taking place today. UN estimates indicate that from 2000 to 2050, the urban population in sub-Saharan Africa will increase from $31 \%$ to 58\% and in Asia from $38 \%$ to $66 \%$ (United Nations 2018). We can anticipate that in the coming decades this will only increase the pressures on speakers of non-dominant languages toward language shift. It does not seem likely that the trend line in Figure 5 for the rest of the world (in which Asia has the largest share of languages) will level off any time soon. Nor does it seem likely that subSaharan Africa can continue to hold off the onset of a sharp rise in language loss.

Figure 5 plots the rate of language doom per generation. Figure 6 uses the same underlying data to graph the extent of language loss by plotting the rise over time of the cumulative total of dead or doomed languages in each region. The three world regions have different numbers of languages, so to make the results per region more comparable, the raw numbers are converted to percentages. The graph shows that $61 \%(919$ of 1,505) of the languages of the Americas and Australia have now become dead or doomed. For sub-Saharan Africa the current extent of language death or doom is $9 \%$ (190 of 2,027) and for the rest of the world it is 17\% (541 of 3736). 


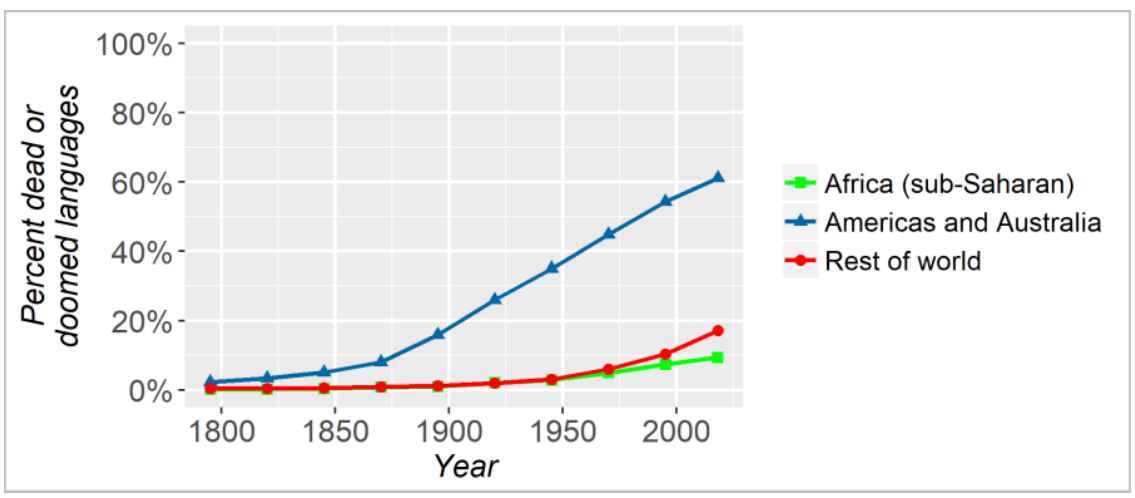

Figure 6. Cumulative extent of language doom by world region

5. Conclusion. The results of this study show that the current rate of language loss is 9 languages per year, which is a far cry from the widely cited, "One language dies every 14 days." However, if the trajectory of spreading language loss maintains its present course, the rate of language loss is likely to reach that level by the middle of the next century. Investigating the trends by world regions shows that a sharp increase in the rate of language doom began in the Americas and Australia by the mid- $19^{\text {th }}$ century; this has progressed to the point that $61 \%$ of those languages are now dead or doomed. In other parts of the world, the current situation is not as dire since a sharp rise in language doom did not begin until the mid-20 $0^{\text {th }}$ century; however, the prospects are sobering. The rapid transition in sub-Saharan Africa and Asia from being approximately two-thirds rural at the start of this century to becoming $58 \%$ and $66 \%$ urban, respectively, by the mid- $21^{\text {st }}$ century will only compound the pressures toward language shift.

\section{References}

Crystal, David. 2000. Language death. Cambridge: Cambridge University Press.

Eberhard, David M., Gary F.Simons, and Charles D Fennig (eds.). 2019. Ethnologue: Languages of the World. Twenty-second edition. Dallas: SIL International. http://www.ethnologue.com/.

Fishman, Joshua A. 1991. Reversing language shift. Clevedon, UK: Multilingual Matters Ltd.

Fishman, Joshua A. (ed.). 2001. Can threatened languages be saved? Reversing language shift revisited: A 21st century perspective. Clevedon, UK: Multilingual Matters Ltd.

Fox, Margalit. 2007. Talking hands: What sign language reveals about the mind. New York: Simon and Schuster.

Krauss, Michael. 1992. The world's languages in crisis. Language 68(1).4-10.

Lewis, M. Paul and Gary F. Simons. 2010. Assessing endangerment: Expanding Fishman's GIDS. Revue Roumaine de Linguistique 55(2).103-120.

Lewis, M. Paul and Gary F. Simons. 2016. Sustaining language use: Perspectives on communitybased language development. Dallas: SIL International.

Lewis, M.Paul, Gary F. Simons, and Charles D. Fennig (eds.). 2014. Ethnologue: Languages of the world. Seventeenth edition. Dallas: SIL International.

Lovelace, Robin, Jakub Nowosad, and James Muenchow. 2019. Geocomputation with R. CRC Press. https://geocompr.robinlovelace.net/.

Moseley, Christopher (ed.). 2010. Atlas of the world's languages in danger. Third edition. Paris: UNESCO Publishing. http://www.unesco.org/culture/en/endangeredlanguages/. 
Mufwene, Salikoko S. 2002. Colonisation, globalisation, and the future of languages in the twenty-first century. International Journal on Multicultural Societies 4(2).162-193.

Rymer, Russ. 2012. Vanishing voices. National Geographic, July 2012, 60-93.

Simons, Gary F. 2011. On defining language development. Presented at International Conference on Language Documentation and Conservation, University of Hawaii, 11-13 February 2011. http://hdl.handle.net/10125/5294.

Simons, Gary F. and Charles D. Fennig (eds.), 2018. Ethnologue global dataset: Twenty-first edition data. Dallas: SIL International. https://www.ethnologue.com/sites/default/files/Ethnologue-21-Global Dataset Doc.pdf

Simons, Gary F and M. Paul Lewis. 2013. The world's languages in crisis: A 20-year update. In Elena Mihas, Bernard Perley, Gabriel Rei-Doval, and Kathleen Wheatley (eds.), Responses to language endangerment. In honor of Mickey Noonan (Studies in Language Companion Series 142), 3-19. Amsterdam: John Benjamins.

UNESCO. 2016. United Nations General Assembly proclaims 2019 as the International Year of indigenous Languages and invites UNESCO to take the lead. United Nations Educational, Scientific and Cultural Organization. http://www.unesco.org/new/en/unesco-liaison-officein-new-york/about-this-office/singleview/news/united_nations_general_assembly_proclaims_2019_as_the_intern/.

United Nations. 2017. Population by age groups-Both sexes (XLSX, 10.31 MB). Population Division: World Population Prospects 2017. https://population.un.org/wpp/Download/.

United Nations. 2018. File 2: Percentage of population at mid-year residing in urban areas by region, subegion and country, 1950-2050. Population Division: World Urbanization Prospects 2018. https://population.un.org/wup/Download/.

Wickham, Hadley. 2010. A layered grammar of graphics. Journal of Computational and Graphical Statistics 19(1).3-28.

Wickham, Hadley and Garrett Grolemund. 2017. $R$ for data science: Import, tidy, transform, visualize, and model data. Sebastopol, CA: O’Reilly Meida. https://r4ds.had.co.nz/.

World Bank. 2019. Life expectancy at birth, total (years). https://data.worldbank.org/indicator/SP.DYN.LE00.IN. 